\title{
EFEKTIVITAS PENGENDALIAN INTERNAL, DAN KOMPETENSI SUMBER DAYA MANUSIA, TERHADAP IMPLEMENTASI GOOD GOVERNANCE SERTA IMPIKASINYA PADA PENCEGAHAN FRAUD DALAM PENGELOLAAN KEUANGAN DESA DI KABUPATEN TANGERANG
}

\author{
Anita Ardiyanti ${ }^{1}$,Yudi Nur Supriadi2 \\ Universitas Muhammadiyah Tangerang, ${ }^{2}$ STISIP Yuppentek Tangerang \\ Aardiyanti96@yahoo.com
}

Keyword
Satisfaction, Quality, Experiential
Marketing, Word Of Mouth

\begin{abstract}
Penelitian ini dilakukan untuk untuk mengetahui dan menganalisis pengaruh sistem pengendalian internal, dan kompetensi sumber daya manusia, terhadap implementasi good governance serta impikasinya pada pencegahan Fraud dalam pengelolaan keuangan desa di Kabupaten Tangerang. Sampel dalam penelitian ini adalah perangkat desa sebanyak 150 responden dengan metode purposive sampling. Teknik analisis data yang digunakan dalam penelitian ini adalah analisis kuantitatif dengan menggunakan model SEM (Structural Equation Modelling) program AMOS 22. Hasil dari penelitian ini menunjukkan bahwa adanya pengaruh yang positif sistem pengendalian internal, dan kompetensi sumber daya manusia, terhadap implementasi good governance serta impikasinya pada pencegahan Fraud dalam pengelolaan keuangan desa di Kabupaten Tangerang secara signifikan. Interpretasi dari hasil penelitian ini akan memiliki arti yang penting untuk menentukan strategi yang jelas dalam meningkatkan pencegahan Fraud dalam pengelolaan keuangan Desa di Kabupaten Tangerang dari hasil perhitungan pengaruh langsung, tidak langsung dan pengaruh total menghasilkan nilai kebaharuan dari sebuah teori dan empirisnya..
\end{abstract}

\section{PENDAHULUAN}

\section{Latar Belakang Masalah}

Pembangunan desa merupakan prioritas program pemerintahan Presiden Joko Widodo (Jokowi) dan Wakil Presiden Jusuf Kalla (JK).Hal ini sebagaimana yang disebutkan dalam Nawa Cita ketiga yaitu membangun Indonesia dari pinggiran dengan memperkuat daerah-daerah dan desa dalam kerangka negara kesatuan. Penguatan desa-desa dilakukan dengan mengucurkan dana desa yang langsung bersumber dari anggaran pendapatan dan belanja Negara (APBN). Pembangunan desa akan semakin menantang dengan kondisi perekonomian daerah yang semakin terbuka dan kehidupan berpolitik yang lebih demokratis. Namun menurut Azam Awang, (2010) mengatakan yang menjadi persoalan adalah desa telah kehilangan identitas dan semangat partisipatif. Sehingga desa sampai saat ini masih belum beranjak dari profil lama, yakni terbelakang dan miskin. Meskipun banyak pihak mengakui bahwa desa mempunyai peranan yang besar bagi kota, namun tetap saja desa masih dipandang rendah dalam hal ekonomi ataupun yang lainnya (Direktorat Permukiman dan Perumahan, 2009).

Potensi bangsa Indonesia sebagian besar penduduknya bertempat tinggal di daerah perdesaan dan berprofesi sebagai petani kecil dan Nelayan. Hal itu ditunjukkan Beberapa tahun terakhir, perkembangan penduduk di 
Indonesia terjadi demikian pesat. Hasil proyeksi yang dilakukan oleh Badan Pusat Statistik Indonesia menunjukkan bahwa jumlah penduduk Indonesia pada tahun 2010 sebanyak237.64I.326 jiwa. Dari jumlah tersebut, sebanyak I19.32I.070 jiwa $(50,21 \%)$ bertempat tinggal di pedesaan, dan sebanyak I I8.320.256 jiwa (49,79\%) tinggal di daerah perkotaan. (Sumber: http://www.bps.go.id diakses pada tanggal 10 Mei 2018). Oleh karena itu, sudah sewajarnya bila pembangunan perdesaan harus menjadi prioritas utama dalam segenap rencana strategi dan kebijakan pembangunan di Indonesia. Jika tidak, maka akan terjadi kesenjangan antara kota dan desa akan semakin tinggi terutama dalam hal perekonomian (Direktorat Permukiman dan Perumahan, 2009).

Pembangunan desa juga menjadi prioritas untuk dilakukan bukan hanya jumlah penduduk Indonesia lebih banyak tinggal di desa, selain itu ada pertimbangan lainnya juga yakni karena sumber daya terbesar bangsa ini ada di pedesaan, khususnya sumber daya alam. Potensinya yang masih banyak terpendam kemudian menjadikan alasan untuk kita menengok kembali arah kebijakan pembangunan yang berpusat pada desa. Tentu pembangunan disini memerlukan keterlibatan aktif warga desa untuk lebih giat dan semangat dalam membangun desanya. Adalah hal yang mustahil sebuah pembangunan dalam skala besar maupun kecil dilaksanakan tanpa biaya. Berangkat dari situasi dan kondisi ini perlu ada alokasi dana khusus bagi pembangunan desa.

Dengan adanya alokasi dana desa maka akan terwujud kesejahteraan masyarakat desa melalui dana ini desa mampu berdaya untuk melaksanakan program pembangunan.

Menurut Noerma Alifahrani Bahtiar, (2017) Diantara pelaksanaan program alokasi dana desa di berbagai desa di Indonesia, ternyata ada pelaksanaan alokasi dana desa yang berhasil atau menghasilkan "best practice". Hal ini berbanding terbalik dengan kenyataan dimana ditengah Indeks Perkembangan Desa turun khususnya di Propinsi Banten yang dapat dilihat pada gambar dibawah ini.

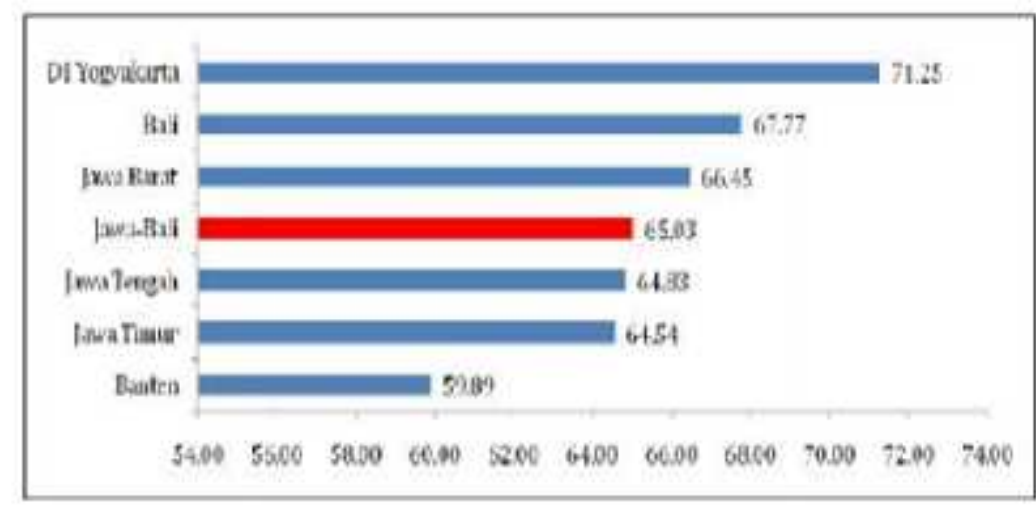

\section{Gambar I. Indeks Perkembangan Desa Pulau Jawa-Bali Tahun 2016} Sumber: BAPPENAS dan BPS, 2016

Pada gambar I diatas indeks perkembangan desa Pulau Jawa-Bali menunjukkan bahwa Banten memiliki indeks terendah yakni sebesar 59, 89. $\mathrm{Hal}$ ini berarti bahwa desa-desa di wilayah Banten masih banyak yang dalam keadaan yangterbelakang dan miskin. Ketimpangan yang diakibatkan salah satunya oleh penerimaan dana desa tersebut sangat mungkin terjadi karena pada kenyataannya pembangunan dan kemajuan yang dialami daerah-daerah di Indonesia ini masih belum merata. Misalnya saja yang terjadi di daerah Jawa Timur yang memiliki ketimpangan yang relatif tinggi diantara daerahdaerahnya

Dalam jumlah dan persentase penduduk miskin di propinsi Banten, pada tahun 2009 sampai tahun 2015 dapat dilihat pada Tabel berikut ini: 
Tabel I. Jumlah dan Persentase Penduduk MiskinPropinsi Banten

Tahun 2009 sampai 2015

\begin{tabular}{|c|c|c|c|c|c|c|c|}
\hline \multirow{2}{*}{ 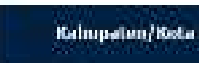 } & \multicolumn{7}{|c|}{ 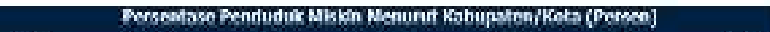 } \\
\hline & 2009 & 2010 & 2011 & 2012 & 2013 & 2014 & 2015 \\
\hline Con Pentikgikeng & 17.01 & 11.14 & 4.50 & $4.2 \pi$ & 10.25 & Q.5. & 1241 \\
\hline Contelas & 18... & 1D. & $7.3 n$ & niks & 89 & E.17 & Q.97 \\
\hline Ges facesiang & t..ss & 7.18 & d., 12 & 2,21 & $5 . / \mathrm{d}$ & S.2. & $5 \% 2$ \\
\hline 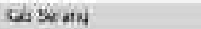 & 3.60 & 5. .94 & $3.9 \mathrm{y}$ & 3,20 & $s .02$ & 4at & $30 \mathrm{~s}$ \\
\hline Lot Ta:oving & 3,42 & 6.8 & 6.14 & 320 & 5.26 & 69 & 504 \\
\hline sora obsen & 1.1.14 & $1,4 \pi$ & 3.58 & 3,62 & 399 & 381 & 4.1: \\
\hline Gilisuraty & $=.19$ & s.tI & 9.75 & $\therefore, \pi$ & $\$ \infty 2$ & $\sin$ & B. 5 \\
\hline Sina Tasoetan? Ratst & te & T. .57 & 1,56 & 47 & $1 . \overline{1}$ & tht & LAF \\
\hline Ravina Barte: & 7.50 & $3 . \mathrm{w} 2$ & j. 26 & 5.71 & $5.6)$ & SS: & so: \\
\hline
\end{tabular}

Sumber : BPS Provinsi Banten 2018

Dari data diatas bahwa jumlah penduduk miskin di perdesaan masih banyak dibandingkan di perkotaan. Jika dilihat perbandingan penduduk Kota Tangerang sebayak $5.0 \quad 4 \%$ sedangkan Kabupaten Tangerang sebayak 5.7I \%. Oleh karena itu, pembangunan di perdesaan perlu diprioritaskan agar dapat meningkatkan kesejahteraan penduduk miskin yang berada di perdesaan. Sedangkan garis kemiskinandi propinsi Banten dapat dilihat pada Tabel 2

Tabel 2. Garis Kemiskinan di propinsi Banten

\begin{tabular}{|c|c|c|c|c|}
\hline \multirow[b]{2}{*}{ Kabupsten/Koth } & \multicolumn{4}{|c|}{ Caris Krysidfinats } \\
\hline & 2017 & 2024 & 2015 & 2016 \\
\hline 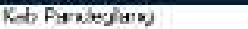 & 230354 & 237111 & 247053 & 267752 \\
\hline kob letaic & 217012 & 210137 & 228144 & 216359 \\
\hline Kah Tangoring & 33501 & 351789 & 372031 & tersoco \\
\hline Kab Serang & 210062 & 223190 & 232856 & 256580 \\
\hline Kora Tungsraed & Mกลร13 & $475 \%$ & 15528 & $4.6 \mathrm{im}$ \\
\hline Rerackism & $795 i n \pi$ & masts & 727035 & 347049 \\
\hline Nota Serang. & 230 cay & $2424 / 1$ & 25 Sol4 & asisaco \\
\hline 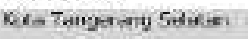 & 378503 & 401695 & $42 x a ?$ & 472958 \\
\hline Prosinsi Bynlen! & 285233 & 315819 & 376480 & 367949 \\
\hline
\end{tabular}

Sumber : BPS Provinsi Banten 2018

Jika melihat data diatas sangat miris dimana posisi Kabupaten Tangerang peringkat ke 3 jumlah garis kemiskinan terbesar yakni 405.902, untuk itu melihat data tersebut harus ada upaya penanggulangan kemiskinan di wilayah perdesaan, sehingga pembangunan desa merupakan bagian penting dalam pembangunan nasional. Berhasilnya pembangunan nasional termasuk pembangunan desa, ditentukan oleh pemerintah melalui berbagai kebijaksanaan di tingkat Provinsi, Kabupaten, Kecamatan, dan Desa.

Pengelolaan keuangan desa, pada dasarnya dilaksanakan untuk mewujudkan desa sebagai suatu pemerintahan terdepan dan terdekat dengan rakyat, yang kuat, maju, mandiri, dan demokratis, hingga mampu melaksanakan penyelenggaraan pemerintahan dan pembangunan menuju masyarakat adil, makmur, dan sejahtera.
Oleh karena itu pemerintah menggulirkan regulasi Undang-Undang Nomor 6 Tahun 2014 tentang Desa yang telah diterjemahkan kembali dalam Peraturan Pemerintah Nomor 22 Tahun 2015 sebagai perubahan atas Peraturan Pemerintah Nomor 60 Tahun 2014 tentang Dana Desa Yang Bersumber Dari Anggaran Pendapatan Dan Belanja Negara sebagai petunjuk pelaksanaannya telah menjadi payung hukum buat perangkat desa dalam melakukan pengelolaan dana desa. Untuk pengelolaan dana desa bukanlah hal yang mudah, namun memerlukan sistem yang juga harus dibuat secara profesional. Mulai dari segi perencanaan, desa harus membentuk musyawarah desa untuk menentukan belanja bagi dana desa pada periode ke depan.

Implementasi Undang-Undang Nomor 6 tahun 2014 tentang Desa diharapkan dapat membawa paradigma baru dalam pembangunan, mampu mengubah cara pandang pembangunan, 
bahwa kesejahteraan dan kemakmuran ekonomi tidak selamanya berada di kota atau perkotaan, tetapi dalam membangun Indonesia haruslah dimulai dari desa, Karena desa menjadi bagian terdepan dari upaya gerakan pembangunan yang berasal dari prakarsa masyarakat, guna mencapai kesejahteraan dan kemakmuran, sekaligus berkeadilan dan berkesinambungan.

Namun, harapan lain yang tidak bisa dikesampingkan adalah dengan adanya bantuan dana desa dari pemerintah, desa dapat terkoneksi untuk menjadi lebih mandiri dan kredibel sehingga mampu memenuhi kebutuhannya sendiri dan tidak semata tergantung dengan bantuan dari pemerintah dan menjadikan bantuan dari pemerintah sebagai stimulant atau perangsang (Wardoyo, 2015:20).

Adanya alokasi Anggaran Pendapatan dan Belanja Negara (APBN) yang diperuntukkan kepada desa dengan anggaran yang cukup besar, sehingga desa menjadi perhatian bagi semua pihak. Dalam pengelolaan keuangan desa tersebut perlu diperhatikan dan ditaati asas umum pengelolaan keuangan desa yaitu, keuangan desa harus dikelola secara tertib, taat pada peraturan perundang-undangan, transparan, akuntabel, dan partisipatif dengan memperhatikan asas keadilan, kepatutan dan manfaat untuk masyarakat desa (Taufik, 2008:15).

Pengelolaan keuangan Desa dilaksanakan dalam masa $I$ (satu) tahun anggaran terhitung mulai tanggal I Januari sampai dengan 31 Desember (Reasoa, 2015:23). Kepala Desa berkewajiban untuk melakukan pengelolaan keuangan desa yaitu berupa semua hak dan kewajiban Desa yang dapat dinilai dengan uang serta segala sesuatu berupa uang dan barang yang berhubungan dengan pelaksanaan hak dan kewajiban Desa. Hak dan kewajiban tersebut kemudian menimbulkan pendapatan, belanja, pembiayaan, dan pengelolaan keuangan Desa.

Dalam rangka mendukung terwujudnya tata kelola yang baik (good governance) dalam penyelenggaraan Desa, pengelolaan keuangan desa dilakukan berdasarkan prinsip tata kelola yaitu transparan, akuntabel dan partisipatif serta dilakukan dengan tertib dan disiplin anggaran. Dalam penganggaran Pengendalian Internal sangat penting untuk mencegah kebijakankebijakan yang menyimpang (Taufik, 2008:26).

Dengan adanya profesionalisme dan kompetensi perangkat desa dalam pengelolaan keuangan desa, maka sangat diharapkan tujuan ekonomi dan sosial pemerintahan desa dapat tercapai. Oleh karena itu, peran serta pihak- pihak di luar pemerintahan desa dan Badan Permusyawaratan Desa (BPD) seperti tokoh desa, tokoh agama, kaum petani, pengusaha desa, serta perwakilan masyarakat lainnya harus bersinergi dan dilibatkan dalam pengelolaan keuangan desa.

Antonius Galih Prasetyo \& Abdul Muis (2015) menyatakan bahwa pengawasan terhadap pengelolaan keuangan desa seharusnya dilakukan secara profesional, ketat, terkontrol dan berintegritas. Penelitian Fikri, dkk (20I5:34) menyatakan bahwa kompetensi perangkat desa dengan pemahaman akuntansi yang kurang menyebabkan pengelolaan keuangan tidak professional sehingga berpotensi terjadi kecurangan. Hal tersebut mengindikasikan bahwa sistem pengendalian internal dan kompetensi perangkat desa harus bersinergi supaya dapat melakukan pencegahan terjadinya Fraud.

Kajian yang dilakukan sejak Januari 20I5, KPK menemukan 14 temuan pada empat aspek, yakni aspek regulasi dan kelembagaan; aspek tata laksana; aspek pengawasan; dan aspek sumber daya manusia. Maka dari itu, untuk memproteksi pengelolaan keuangan desa dari tindakan Fraud, perlu adanya sistem pengendalian internal yang baik pula, sehingga segala tindak kecurangan dapat dicegah. Namun, sistem pengendalian akan berjalan dengan baik jika didukung oleh sikap dan budaya personal yang baik atau yang sering disebut dengan moralitas (Purwitasari, 2013:33).

Fadilah (2011:30) menyatakan bahwa sistem pengendalian internal memiliki pengaruh langsung terhadap Good governance sehingga berimplikasi terhadap pencegahan Fraud. namun, sistem pengendalian internal tidak luput dari kelemahannya, kelemahan ini dapat dimanfaatkan oleh oknum pelaku kecurangan (Martani dan Zaelani, 20II:I5). Jika kelemahan sistem ini didukung oleh moralitas perangkat desa yang baik, maka segala jenis kecurangan dapat dicegah, seperti hasil penelitian dari Salindeho (2017:2I) menyatakan bahwa moralitas perangkat desa pemerintahan yang dinyatakan dalam etika pemerintah memiliki pengaruh yang kuat terhadap Pencegahan Fraud pemerintahan tersebut.

Kompetensi perangkat desa, sistem pengendalian internal yang memadai serta peran aktif masyarakat desa dipandang perlu untuk diperhatikan dalam pengelolaan keuangan desa, terlebih disinyalir banyak permasalahan yang terjadi dalam pengelolaan keuangan bahwa penyaluran dana desa serta pengelolaannya 
rentan terjadi korupsi, hal ini didukung oleh pernyataan dari Kepala Badan Pemeriksa Keuangan RI Perwakilan Jawa Barat, Kornel Syarif Prawiradiningrat, mengingatkan agar para kepala desa ekstra hati-hati mengelola dana perimbangan. Permasalahan seperti ini tidak menutup kemungkinan juga terjadi didaerahdaerah lain termasuk di Provinsi Banten, data BPS pada tahun 2015 berjumlah 1.238 desa. Terutama di kabupaten terbanyak menerima dana, pada tahun 2015 jumlah desa di Kabupaten Tangerang sebanyak 246 Desa.

Menurut Data Pemerintah Provinsi Banten melalui Badan Pemberdayaan Perempuan dan Masyarakat Desa (BPPMD) Banten menyalurkan bantuan keuangan desa Tahun anggaran 2017 untuk 1.237 desa di empat kabupaten di Banten berada di Kabupaten Pandeglang, Kabupaten Lebak, Kabupaten Serang dan Kabupaten Tangerang masing-masing Rp20 juta. Tahun ini bantuan desa yang diberikan masing-masing Rp 20 juta. pada 2017 nanti naik menjadi masing-masing $R p 30$ juta kepada I.238 desa," (http://www.wartaekonomi.co.id. 29 Agustus 2017).
Untuk kabupaten Tangerang mendapatkan alokasi dana tahun 2017 desa di 3I desa yakni : Desa Sodong, Desa Matagara Kecamatan Tigaraksa, Desa Pasir Gadung Kecamatan Cikupa, Desa Cihuni, Desa Situgadung Kecamatan Pagedangan, Desa Gandawati, Desa Cipaeh, Desa Ranca Gede Kecamatan Gunung Kaler, Desa Kronjo, Desa Waliwis, Desa Cijeruk, Desa Jenggot, Desa Kedaung Kecamatan Mekar Baru, Desa Jatiwaringin, Desa Ketapang Kecamatan Mauk, Desa Kemiri, Desa Gintung, Desa Sukadiri, Desa Daon, Desa Mekar Sari, Desa Rajeg, Desa Sukamanah, Desa Pangarengan, Desa Rancabamgo, Desa Tanjakan Desa Rawa Boni, Desa Sukawali, Desa Kramat, Desa Kali Baru, Desa Kohod Kecamatan Pakuhaji. Untuk alokasi dana desa sebesar Rp. 308.379.347. Bagi hasil pajak dan retribusi sebesar Rp. 201.753.796. Dana desa 884.284.944. Jumlah total Rp. I.394.4I8.087. Untuk Kabupaten Tangerang alokasi dana desa yang berasal dari APBN sebesar Rp 215 Miliar bagi 246 Desa di Kabupaten Tangerang. Dana tersebut sudah dicairkan Pemkab Tangerang sebesar 60\%. (https://bantensatu.co, 29 Agustus 2017). dapat dilihat pada Tabel berikut:

Tabel 3. Pagu Dana Desa di Kabupaten Tangerang

\begin{tabular}{|c|c|c|}
\hline NO & $\begin{array}{l}\text { URAIAN- } \\
\text { URAIAN }\end{array}$ & KETERANGAN \\
\hline 1 & $\begin{array}{l}\text { Pagu Dana Desa Kabupaten } \\
\text { Tangerang }\end{array}$ & 168.759 .814 .000 \\
\hline 2 & $\begin{array}{l}\text { Hasil Perhitungan Pagu Dana Desa } \\
\text { Kabupaten Tangerang }\end{array}$ & 168.759 .814 .000 \\
\hline 3 & Pagu Alokasi Dasar & 565.640 .000 \\
\hline 4 & Total Pagu Alakasi Dasar & 139.147 .440 .000 \\
\hline 5 & Pagu Alokasi Formulasi & 29.612 .374 .000 \\
\hline$\sigma$ & Total Pagu Alokasi Formula & 29.612 .374 .000 \\
\hline 7 & Jumlah Desa & 246 \\
\hline
\end{tabular}

Sumber : Bappeda Kab. Tangerang 2018

Menurut Badan Pengawasan Keuangan dan Pembangunan RI (20I5 :6) Beberapa risiko kecurangan (Fraud) yang dapat terjadi dalam pengelolan keuangan desa, antara lain :Pertama, Penggunaan Kas Desa secara tidak sah (Theft of Cash on Hand). Risiko ini merupakan penggunaan kas desa secara tidak sah oleh perangkat atau pihak lainnya. Pencurian merupakan salah satu bentuk kecurangan yang keuangan desa hingga mengurangi kemampuan pemerintah desa dalam menjalankan tugas danfungsinya.

Kedua, mark up dan atau kick back pada Pengadaan Barang/Jasa. Meninggikan harga beli barang/jasa dari harga wajarnya dan selanjutnya ada pengembalian sejumlah kas kepada perangkat terkait merupakan bentuk kecurangan yang sudah sering terjadi. Apalagi dalam kondisi sistem pengendalian pemerintahan desa yang belum matang, kemungkinan terjadinya risiko ini cukup tinggi. Hal ini tentunya dapat menimbulkan kerugian keuangan desa dan mengurangi kemampuan pemerintah dengan menjalankan tugas dan fungsinya.

Ketiga, Penggunaan Aset Desa untuk kepentingan pribadi Perangkat Desa secara tidak Sah (misuse atau larceny) Aset desa, berupa sarana kantor, tanah desa, peralatan kantor ataupun kendaraan kantor seharusnya digunakan untuk mendukung pelaksanaan tugas dan fungsi pemerintahan desa. Namun seringkali, peralatan tersebut digunakan untuk kepentingan pribadi, atau bahkan dimiliki secara tidak sah. Ini risiko 
yang juga sering terjadi pada institusi yang sistem pengendaliannya belum matang seperti pada umumnya pemerintahan desa. Hal ini dapat menganggu operasional institusi.

Pada pemerintah desa sebagai pihak yang melaksanakan langsung pengelolaan keuangan desa, terdapat beberapa titik kritis yang harus menjadi perhatian bersama, yaitu kondisi sumber daya manusia Kepala Desa, Perangkat Desa dan BPD. Kemudian terkait sarana dan prasarana desa, serta kebijakan tingkat desa juga menjadi salah satu titik kritis. Titik kritis dalam proses pengelolaan keuangan desa dapat dilihat dari bisnis prosesnya. Mulai dari tahapan perencanaan, harus diperhatikan keselarasan perencanaan dalam RPJM dan RKP Desa dengan Program Pemerintah Pusat, Provinsi dan Kabupaten/ Kota, tingkat partisipasi BPD dan kualitas RKP Desa. Pada tahapan penganggaran, perlu diperhatikan unifikasi dan integrasi penyusunan anggaran, harmonisasi Kades \& BPD, dan evaluasi APB Desa oleh Kecamatan.

Titik kritis dalam tahap penatausahaan, antara lain pada administrasi pembukuan, cara menyusun pertanggungjawaban, pencatatan kekayaan desa, dan konsep belanja barang dan belanja modal yang masih rancu. Disisi pelaporan dan pertanggungjawaban, titik kritisnya adalah pemahaman tentang jumlah laporan yg harus dibuat dan standar pelaporannya. Terakhir, pengawasan merupakan titik kritis yang harus diperhatikan terutama terkait efektifitas pengawasan dan kesiapan perangkat pengawasan khususnya Kabupaten/Kota.

Pemberian dana ke desa yang begitu besar, jumlah pelaporan yang beragam serta adanya titik kritis dalam pengelolaan keuangan desa tentunya menuntut tanggung jawab yang besar pula oleh Perangkat Pemerintah Desa. Oleh karena itu, pemerintah desa harus bisa menerapkan prinsip akuntabilitas dalam pengelolaan keuangan desa, dimana semua akhir kegiatan penyelenggaraan Pemerintah Desa harus dapat dipertanggungjawabkan kepada masyarakat desa sesuai ketentuan sehingga terwujud tata kelola pemerintahan desa yang baik (Good Village Governance).

Pemerintah desa yang telah mewujudkan Good Village Governance, memiliki indikator, antara lain: pertama, tata kelola keuangan desa yang baik. Kedua, perencanaan desa yang partisipatif, terintegrasi dan selaras dengan perencanaan daerah dan nasional. Ketiga, berkurangnya penyalahgunaan kekuasaan/ kewenangan yang mengakibatkan permasalahan hukum.

Keempat, mutu pelayanan kepada masyarakat meningkat. Untuk dapat menerapkan prinsip akuntabilitas tersebut diperlukan berbagai sumber daya dan sarana pendukung, diantaranya SDM yang kompeten serta dukungan sarana teknologi informasi yang memadai dan dapat diandalkan.

Dengan adanya dana desa yang tepat sasaran, tepat jumlah, dan tepat waktu, serta dikelola dengan efisien, efektif, dan ekonomis, diharapkan kesejahteraan masyarakat dapat meningkat dengan cepat terutama bagi masyarakat desa dalam peningkatan kesejahteraannya. Akan tetapi jika tidak didukung oleh kompetensi sumber daya perangkat desa yang baik, pengendalian internal dan implementasigood governance, dipastikan akan terjadi kecurangan atau Fraud dalam pengelolaan keuangan Desa di Kabupaten Tangerang.

\section{Rumusan Masalah}

Berdasarkan pemaparan tersebut penulis ingin membuktikan apakah efektivitas sistem pengendalian internal dan kompetensi sumber daya perangkat desa yang baik berpengaruh terhadap implementasi good governance serta implikasinya pada pencegahan kecurangan atau Fraud dalam pengelolaan keuangan Desa di Kabupaten Tangerang ?

\section{TINJAUAN PUSTAKA}

a. Pengaruh Sistem Pengendalian Internal terhadap Implementasi Good governance

Dalam Standar Profesional Akuntan Publik (200I: 319) yang diterbitkan oleh Ikatan Akuntan Indonesia (IAI) menyatakan bahwa pengendalian intern adalah suatu proses dengan tujuan untuk memberikan keyakinan memadai tentang pencapaian keandalan informasi, kepatuhan terhadap hukum dan peraturan yang berlaku, serta efektifitas dan efisiensi operasi oleh dewan komisaris dan manajemen, serta personel lainnya.

Sehingga pengendalian intern bukanlah suatu tujuan melainkan proses pengendalian untuk mencapai tujuan yang saling berkaitan diantaranya pelaporan keuangan, kepatuhan, dan operasi yang bukan hanya terdiri dari pedoman kebijakan dari formulir akan tetapi dijalankan oleh orang dari setiap pemegang organisasi yang terdiri dari dewan komisaris, manajemen dan 
personel lainnya. Dengan demikian pengendalian intern diharapkan mampu memberikan keyakinan yang memadai terlepas dari keterbatasan yang melekat dalam pengendalian intern sehingga menyebabkan pengendalian intern tidak dapat memberikan keyakinan mutlak (Ratnayani, Sujana, Ari, \& Darmawan, 20I4)

Menurut Mulyadi (2002: 183) dalam bukunya Auditing, terdapat lima unsur pokok pengendalian intern yaitu lingkungan pengendalian, penetapan risiko, aktivitas pengendalian, informasi dan komunikasi akuntansi, dan pemantauan. Agar kegiatan dan kelancaran operasional instansi dapat dipertahankan maka diperlukan suatu jaminan terhadap aset kas milik instansi untuk menghindari penyelewengan atau penyalahgunaan aset kas oleh para pegawainya karena akan berpengaruh terhadap kelancaran operasional sehari- hari. Memberikan perhatian secara serius terhadap perencanaan dan pengendalian kas yang merupakan sumber atau sasaran yang paling mudah untuk disalahgunakan dan pada akhirnya berdampak pada laporan keuangan. Laporan keuangan dalam entitas pemerintahan sangat erat hubungannya dengan kepentingan publik sehingga seharusnya laporan keuangan disajikan secara wajar dan tidak mengandung unsur kecurangan.

Efektivitas pengendalian internal juga merupakan faktor yang berpengaruh terhadap adanya tindak kecurangan akuntansi. Pengendalian internal yang lemah atau longgar dapat memberikan peluang seseorang untuk melakukan perilaku kecurangan akuntansi yang dapat merugikan suatu instansi atau lembaga (Kadek, Wijaya, Sujana, \& Purnamawati, 20I7)

Upaya penetapan Tap. MPR RI

No.XI/MPR/I998 dan Undang-undang No.28 tahun 1999 tentang Penyelenggara Negara yang Bersih dan Bebas Korupsi, Kolusi, dan Nepotisme menimbulkan suatu tujuan untuk mewujudkan pemerintahan yang baik/amanah (Good governance) dimana menjadi prasyarat bagi setiap pemerintahan untuk memenuhi aspirasi masyarakat dan mencapai tujuan serta cita-cita bangsa dan negara. Dalam hal ini Good governance memiliki pengertian sebagai pelayanan publik yang efisien, sistem pengadilan yang dapat diandalkan, pemerintahan yang bertanggung jawab (accountable) pada publiknya. Sehubungan dengan penyelenggaraan pemerintahan, akuntabilitas pemerintah tidak dapat diketahui apabila pemerintah tidak memberitahukan kepada rakyat tentang informasi sehubungan dengan pengumpulan sumber daya dan sumber dana masyarakat beserta penggunaannya (Ratnayani et al., 20l4). Sistem Pengendalian Intern (SPI) berpengaruh positif dan signifikan terhadap Penerapan Good governance, (Ristanti, Sinarwati, \& Sujana, 20।4)

Berdasarkan Teori diatas maka dirumuskan hipotesis: "terdapat Pengaruh Sistem Pengendalian Internal terhadap Implementasi Good governance".

b. Pengaruh Efektivitas Sistem Pengendalian Internal Terhadap pencegahan Fraud

Menurut PP No. 8 Tahun 2006 pengendalian internal adalah suatu proses yang dipengaruhi oleh manajemen yang diciptakan untuk memberikan keyakinan yang memadai dalam pencapaian efektivitas, efisiensi, ketaatan terhadap peraturan perundang-undangan yang berlaku dan keandalan penyajian laporan keuangan. Pengendalian intern merupakan suatu proses untuk mencapai tujuan tertentu.

Pengendalian intern merupakan suatu rangkaian tindakan yang menjadi bagian tidak terpisahkan, bukan hanya sebagai tambahan dari infra struktur perusahaan. Kecurangan (Fraud) merupakan suatu kesalahan yang dilakukan secara sengaja yang dilakukan untuk tujuan pribadi atau orang lain dimana tindakan tersebut telah menyebabkan kerugian pihak tertentu atau instansi tertentu (Oktariani Wefa, 20I7).

Kas menurut pengertian akuntansi adalah alat pertukaran yang dapat diterima untuk pelunasan piutang, dapat diterima sebagai setoran ke bank dengan jumlah sebesar nominalnya, juga simpanan dalam bank atau tempat lain yang dapat diambil sewaktu- waktu. dalam prakteknya, kadang kas dikelompokkan menjadi dua yaitu kas kecil dan kas besar. Kas kecil digunakan untuk operasional sehari-hari dan jumlahnya tidak terlalu besar. Biaanya digunakan untuk biaya operasional seperti biaya administrasi, biaya telepon, listrik, dll. Kas besar biasanya digunakan untuk menampung penerimaan piutang, pinjaman bank, pengeluaran untuk membayar utang, pengeluaran untuk membeli aktiva (Oktariani Wefa, 2017). Penerapan Pengendalian

Intern Kas diukur melalui 5 indikator, yaitu : (I) Lingkungan pengendalian (2) Penetapan Resiko (3) Informasi Komunikasi (4) Aktifitas Pengendalian (5) Pemantauan

Kecenderungan kecurangan (Fraud) akuntansi atau yang dalam bahasa pengauditan disebut dengan Fraud akhir-akhir ini menjadi 
berita utama dalam pemberitaan media yang sering terjadi. Dalam lingkup akuntansi, konsep kecurangan atau Fraud merupakan penyimpangan dari prosedur akuntansi yang seharusnya tidak diterapkan dalam suatu entitas (Kadek et al., 2017)

Sistem pengendalian intern yang baik memiliki pengaruh yang besar terhadap kelangsungan perusahaan, karena itu perusahaan dapat melaksanakan seluruh aktifitasnya sesuai dengan tujuan dan sasaran yang ingin dicapai, jika tujuan perusahaan telah tercapai berarti tindakan yang dilakukan manajemen telah sesuai dengan peraturan dan tidak ada tindakan yang merugikan perusahaan (Wilopo, 2006).

Pengendalian intern kas berpengaruh terhadap Fraud pada perusahaan BUMN di kota Pekanbaru. Semakin besar jumlah kas dalam perusahaan berarti semakin tinggi pula tingkat likuiditasnya semakin tinggi tingkat penerapan pengendalian intern kas di perusahaan BUMN maka semakin rendah akan terjadinya Fraud di perusahaan BUMN di kota Pekanbaru (Oktariani Wefa, 20l7)

Berdasarkan Teori diatas maka dirumuskan hipotesis: “ Terdapat pengaruh Efektivitas pengaruh Pengendalian internal Terhadap pencegahan Fraud"

c. Pengaruh Kompetensi Sumber Daya Manusia terhadap implementasi Good governance

Menurut Halim (2010), kualitas dan kinerja suatu organisasi sangat ditentukan oleh SDM, karena dalam suatu organisasi keberadaan SDM tidak tergantikan oleh faktor lain. Kaitannya dengan kualitas SDM pada pemerintah daerah saat ini, menunjukkan bahwa perangkat yang bekerja dalam mengelola keuangan daerah belum dapat menyusun laporan secara komprehensif (berupa neraca, laporan arus kas, dan laporan realisasi anggaran) disebabkan karena baru memahami sebagian materi atau konsep akuntansi dan manajemen keuangan. Faktor-faktor yang dapat mempengaruhi produktivitas manusia dalam menentukan keberhasilan suatu organisasi menurut Sunyoto (20I2) antara lain pengetahuan (knowledge), keterampilan (skills), kemampuan (abilities), sikap (attitude), dan perilaku (behavior)

Kegagalan SDM Pemerintah Daerah dalam memahami dan menerapkan logika akuntansi akan berdampak pada kekeliruan laporan keuangan yang dibuat dan ketidaksesuaian laporan dengan standar yang ditetapkan pemerintah (Warisno, 2008).
Kompetensi SDM mencakup kapasitasnya, yaitu kemampuan seseorang atau individu, suatu organisasi (kelembagaan), atau suatu sistem untuk melaksanakan fungsi- fungsi atau kewenangannya untuk mencapai tujuannya secara efektif dan efisien. Kapasitas harus dilihat sebagai kemampuan untuk mencapai kinerja, untuk menghasilkan keluaran-keluaran (outputs) dan hasil-hasil (outcomes). Laporan keuangan adalah suatu produk yang dihasilkan oleh bidang atau dari disiplin ilmu akuntansi, oleh karenanya diperlukan SDM yang berkompeten dalam menyusun dan menghasilkan laporan Keuangan yang berkualitas. Untuk menghasilkan Laporan Keuangan Pemerintah yang berkualitas diperlukan atau dibutuhkan SDM yang memahami dan berkompeten dalam melaksanakan akuntansi keuangan Pemerintah Daerah serta organisasional tentang pemerintahan.

Kompetensi SDM memiliki hubungan yang positif terhadap kualitas LKPD karena dalam menyusun dan menghasilkan laporan keuangan yang berkualitas SDM memiliki peran yang sangat penting khususnya SDM di bidang akuntansi, seperti yang telah diteliti oleh Arsyiati (2008) menemukan bukti empiris dan menyimpulkan bahwa pengaruh SDM dalam pengelolaan keuangan terhadap kualitas pertanggungjawaban keuangan dilihat koefisien jalur mempunyai arah yang positif yang artinya SDM mempunyai pengaruh terhadap kualitas pertanngungjawaban keuangan.

Penelitian Yuliani (20/2) menemukan bukti bahwa kompetensi SDM bidang akuntansi memiliki pengaruh yang positif dan signifikan terhadap kualitas LKPD. SDM merupakan modal utama dalam suatu organisasi, yang meliputi pengetahuan, keterampilan, dan kemampuan seseorang yang dapat digunakan dalam menghasilkan suatu layanan yang profesional

Penerapan Good governance merupakan variabel moderating yang dapat memoderasi hubungan antara sistem pengendalian intern pemerintah, implementasi standar akuntansi pemerintahan, penyelesaian temuan audit dan kompetensi SDM dengan kualitas laporan keuangan pemerintah Kabupaten Samosir (Meldawati Girsang, 20I I).

Hasil penelitian (Washliati, 2015) mengatakan bahwa Pengaruh kompetensi sumber daya manusia dalam mewujudkan good governance di Inspektorat Kabupaten Labuhanbatu Utara Berdasarkan hasil penelitian yang telah dilakukan sebelumnya, pada uji signifikansi dapat diketahui bahwa kompetensi 
Sumber Daya Manusia berpengaruh dalam mewujudkan Good governance di Inspektorat Kabupaten Labuhan batu Utara, sehingga dapat disimpulkan apabila kompetensi sumber daya manusia di Inspektorat Kabupaten Labuhanbatu Utara ditingkatkan maka pelaksanaan good governance dapat diterapkan dengan lebih baik

Berdasarkan Teori diatas maka dirumuskan hipotesis: “ Terdapat Pengaruh Kompetensi Sumber Daya Manusia terhadap Implementasi Good governance"

\section{d. Pengaruh Kompetensi Sumber Daya Manusia terhadap pencegahan Fraud}

Kompetensi adalah kualifikasi yang dibutuhkan auditor untuk melaksanakan audit dengan benar. Dalam melaksanakan audit, seseorang auditor harus memiliki mutu personal yang bauik, pengetahuan yang memadai, serta keahlian khusus dibidangnya (Agusyani, Sujana, \& Wahyuni, 2016).

Hasil penelitian Taufik (2008) yang menyatakan bahwa kompetensi sumber daya manusia berpengaruh signifikan terhadap pendeteksian Fraud. Hasil peneltian widiyastuti dan pamudji (2009) menyatakan bahwa kompetensi SDM berpengaruh positif terhadap kemampuan auditor dalam mendeteksi kecurangan (Fraud)

Sehingga dengan kompetensi sumber daya manusia yang baik, maka semakin tinggi karyawan untuk tidak melakukan tindakan Fraud. $\mathrm{Hal}$ ini karena sumber daya manusia tersebut telah memiliki pengetahuan dan pemahaman mengenai pencegahan Fraud.

Berdasarkan konsep-konsep tersebut, tampak bahwa kompetensi sumber daya manusia dan pencegahan Fraud berbanding lurus, jika semakin baik kompetensi sumber daya manusia pegawai, maka semakin tinggi juga pegawai untuk tidak melakukan tindakan Fraud. Karena semakin bagus tingkat kompetensi sumber daya manusia maka pemahaman mengenai Fraud sebagai upaya pencegahan dan pendeteksian Fraud maka potensi terjadinya tindakan Fraud semakin kecil. Sehingga kompetensi sumber daya manusia berpengaruh positif dan signifikan terhadap pencegahan Fraud

Berdasarkan Teori diatas maka dirumuskan hipotesis: “ Terdapat Pengaruh Kompetensi Sumber Daya Manusia terhadap pencegahan Fraud". e. Pengaruh implementasi good governance terhadap pencegahan Fraud

Menurut Mardiasmo (2008) Good governance merupakan penyelenggaraan manajemen pembangunan yang solid dan bertanggungjawab yang sejalan dengan prinsip demokrasi dan pasar yang efesien, penghindaran salah alokasi dana investasi dan pencegahan korupsi baik secara politik maupun administrasi, menjalankan disiplin anggaran serta menciptakan legal and political framework bagi tumbuhnya aktivitas usaha

Penelitian Wilopo (2006) menemukan bahwa penerapan pengendalian intern berpengaruh signifikan negatif terhadap kecurangan. Adanya pengendalian intern yang efektif atas kas dapat memperketat pengawasan untuk tidak berprilaku curang.

Sesuai dengan hasil penelitian Fitriatil Husna (2008) bahwa pengendalian intern kas dan implementasi Good Corporate Governance secara simultan berpengaruh negatif terhadap Fraud. Tujuan penerapan Good governance menurut Forum for Corporate Governance in Indonesia (FCGI) adalah untuk memastikan bahwa sasaran perusahaan yang ditetapkan telah tercapai dan berupaya menjaga aset perusahaan serta melaksanakan praktik- praktik usaha yang sehat.

Apabila keefektifan pengendalian intern atas kas dan implementasi Good governance suatu instansi dapat ditingkatkan maka transparansi dan pelaksanaan fungsi akuntansi akan semakin baik dan dapat menekan kecurangan kas. Sehingga diduga terdapat hubungan negatif antara pengendalian intern kas dan implementasi (Ratnayani et al., 20I4)

Hasil penelitian (Ratnayani et al., 2014) menjelaskan secara parsial dapat diketahui bahwa Implementasi Good governance berpengaruh signifikan negatif terhadap Fraud pada SKPD di Kabupaten Buleleng. Hal ini berarti semakin tinggi implementasi Good governance maka semakin rendah Fraud pada SKPD di Kabupaten Buleleng

Dari penjelasan di atas, teori dapat diringkas sebagai argumen berdasarkan definisi dan hipotesis yakni $\mathrm{HI}$ : terdapat Pengaruh Sistem Pengendalian Internal terhadap Implementasi Good governance, H2: Terdapat pengaruh Efektivitas Pengendalian internal Terhadap pencegahan Fraud, H3 : Terdapat Pengaruh Kompetensi Sumber Daya Manusia terhadap Implementasi Good governance, H4 : Terdapat Pengaruh Kompetensi Sumber Daya 
Manusia terhadap Implementasi Good governance, $\mathrm{H} 5$ : terdapat pengaruh implementasi good governance terhadap pencegahan Fraud, kerangka acuan penelitian dijelaskan berikut ini:

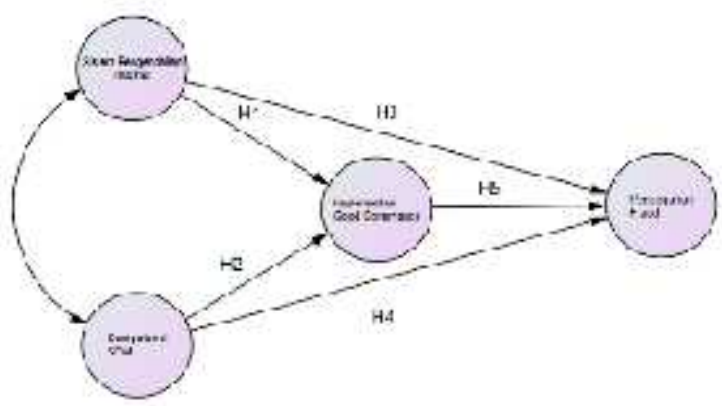

Gambar 2. kerangka acuan penelitian

\section{METODE PENELITIAN}

Penelitian ini dilakukan di Desa sekabupaten Tangerang, terutama perangkat desa dengan sampel sebanyak 150 responden. Objek penelitian yaitu Efektivitas Pengendalian Internal, Kompetensi Sumber Daya Manusia, Implementasi Good governance dan Pencegahan Fraud dalam Pengelolaan Keuangan Desa di Kabupaten Tangerang. pengumpulan data dilakukan melalui pengumpulan data di lapangan.Metode penelitian yang digunakan adalah metode survey, yaitu penelitian yang dilakukan pada suatu populasi dengan menganalisis data yang diperoleh dari suatu populasi dan penelitian terhadap perilaku. Tipe investigasi menggunakan tipe korelasi (ada atau tidaknya hubungan) dan kausatitas (adanya hubungan sebab akibat)

Penarikan sampel yang terlalu banyak akan memerlukan biaya yang besar, oleh karena itu, peneliti perlu menentukan jumlah sampel yang layak, yaitu jumlah sampel yang dapat mencerminkan keadaan populasi, sementara penghematan waktu dan biaya penelitian juga masih dapat diperoleh.

Untuk menganalisis data digunakan The Structural Equation Modeling dari paket software statistik AMOS dalam model dan pengkajianhipotesis. Model persamaan structural, Structural Equation Model (SEM) adalah sekumpulan teknik-teknik statistical yang memungkinkan pengujian sebuah rangkaian hubungan relatif "rumit" secara simultan (Ferdinand, 20I4).

Keunggulan aplikasi SEM dalam penelitian manajemen adalah karena kemampuannya untuk mengkonfirmasi dimensi-dimensi dari sebuah konsep atau factor yang sangat lazim digunakan dalam manajemen serta kemampuannya untuk mengukur pengaruh hubungan-hubungan yang sudah dibentuk secara teoritis.

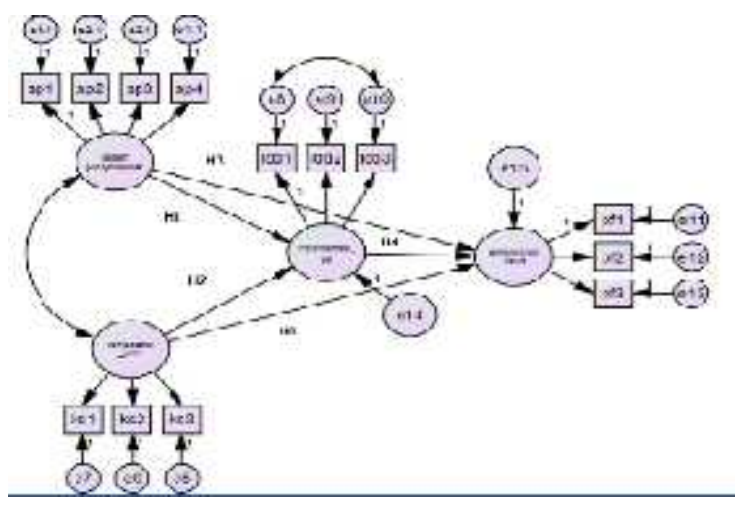

\section{Gambar. 3 Model Teoritik Penelitian}

\section{Analisis Structural Equation Modelling (SEM)}

Analisis selanjutnya adalah analisis Structural Equation Model (SEM) secara full model, setelah dilakukan analisis terhadap tingkat uni dimensionalitas dari indikatorindikator pembentuk variabel laten yang diuji dengan confirmatory factor analysis.
Analisis hasil pengolahan data pada tahap full model SEM dilakukan dengan melakukan uji kesesuaian dan uji statistik. Hasil pengolahan data untuk analisis full model SEM ditampilkan pada Gambar dibawah ini: 


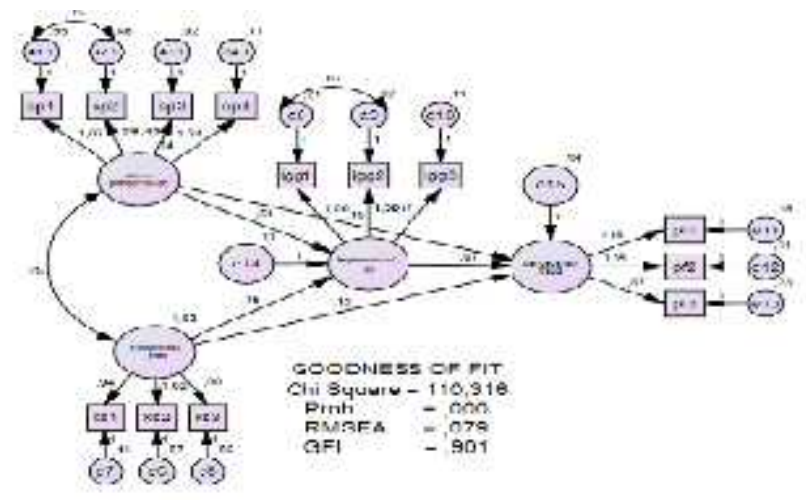

Gambar. 4 Hasil Analisis Structural Equation Modelling

\section{Pengujian Hipotesis}

Penujin hipotesis penelitian menurut siswoyo (2017) dilakukan terhadap 5 hipotesis yang diajukan. Pengujian hipotesis ini dilakukan dengan menggunakan nilai t-value dengan tingkar signifikasi 0,05 . Nilai t-value dalam program Amos 22,00 merupakan nilai Critical Ratio (C.R) pada regression weight (Group Number I Default model) dari fit model apabila nilai critical ratio $(C R) \geq 1,967$ atau nilai probilitas $(P) \leq$ 0,05 maka $\mathrm{H}_{0}$ ditolak (hipotesis peneliian diterima). Nilai regresstion Weights : (group number I- default model) hasil pengolahn Amos 22,00 terhadap model tabel berikut ini :

Tabel4. Regression Weight (Group number I-Defaul model)

\begin{tabular}{|c|c|c|c|c|c|}
\hline & & Estimule & S.E. & C.F. & $\mathbf{F}$ \\
\hline imblementosi कy <- & sis.tm teingerjolis! & .515 & $1 \% 4$ & 4,501 & $\because$ \\
\hline Implementasl $\mathrm{ca}<-$ & competensi sim & .54 & .04 & 3,782 & -4 \\
\hline 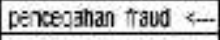 & \$s.em pengendallan & .754 &, 132 & 1,239 & .215 \\
\hline pencejahan_fraud <- & komaelensi_sidm & 91 & .055 & 3,456 & -4 \\
\hline Denceozhan traud <-. & imementas od & .655 & .163 & 4. 02 & -4 \\
\hline
\end{tabular}

Sumber : Analisis hasil penghitungan, 2018

Dari tabel diatas dijadikan sebagai acuan utama untuk melakukan uji hipotesis dalam penelitian ini. Kriteria pengujian adalah tolak $\mathrm{H}_{0}$, jika nilai v-value atau critical ratio $(C R) \geq 1,967$ atau nilai $p \leq 0,05$. Berdasarkan tabel diatas dapat diagram koefeseien $t$ hitung hasil analisis Structural Equation Modelling sepertu pada gambar berikut ini :

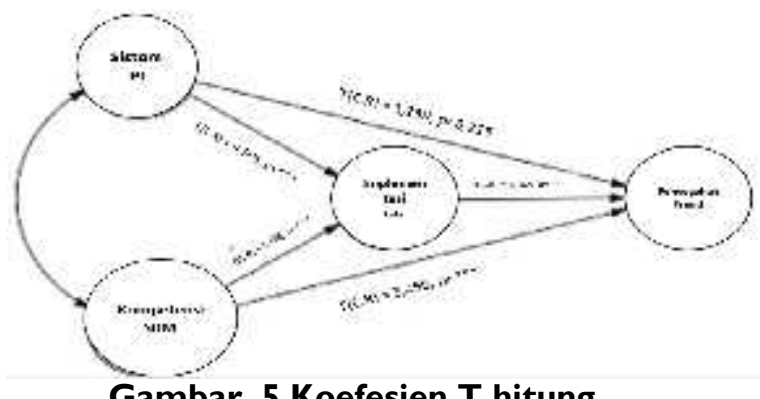

\section{HASIL PENELITIAN DAN PEMBAHASAN}

\section{Hasil Penelitian}

Adapun hasil pengujian terhadap seluruh hipotesis yang diajukan dalam penelitian ini adalah sebagai berikut :

$\mathrm{HI}$ : diketahui hasil analisis data, dimana nilai vvalue atau critical ratio sebesar $4,501 \geq$ 1,967 atau nilai $P$ sebesar $0,000 \leq 0,05$ maka $\mathrm{HI}$ diterima, disimpulkan bahwa Sistem Pengendalian Internal berpengaruh positif terhadap Implementasi Good governance.

$\mathrm{H} 2$ : diketahui hasil analisis data, dimana nilai vvalue atau critical ratio sebesar $1,239, \geq$ I,967 atau nilai $P$ sebesar $0,215 \leq 0,05$ maka $\mathrm{HI}$ diterima, disimpulkan bahwa terdapat pengaruh positif efektivitas Pengendalian internal Terhadap pencegahan Fraud

H3 : diketahui hasil analisis data, dimana nilai vvalue atau critical ratio sebesar $3,788, \geq$ I,967 atau nilai $P$ sebesar $0,000 \leq 0,05$ maka HI diterima, disimpulkan bahwa Terdapat Pengaruh positif Kompetensi Sumber Daya Manusia terhadap Implementasi Good governance,

$\mathrm{H} 4$ : diketahui hasil analisis data, dimana nilai vvalue atau critical ratio sebesar $3,788, \geq$ I,967 atau nilai $P$ sebesar $0,000 \leq 0,05$ maka $\mathrm{HI}$ diterima, disimpulkan bahwa terdapat Pengaruh secara positif Kompetensi Sumber Daya Manusia terhadap Implementasi Good governance,

H5 : diketahui hasil analisis data, dimana nilai vvalue atau critical ratio sebesar $4,102 \geq$ I,967 atau nilai $P$ sebesar $0,000 \leq 0,05$ maka $\mathrm{HI}$ diterima, disimpulkan bahwa terdapat pengaruh yang positif 
implementasi good governance terhadap pencegahan Fraud

\section{Pembahasan}

Berdasarkan Hasil dari penelitian ini menunjukkan bahwa adanya pengaruh yang positif sistem pengendalian internal, dan kompetensi sumber daya manusia, terhadap implementasi good governance serta impikasinya pada pencegahan Fraud dalam pengelolaan keuangan desa di Kabupaten Tangerang secara signifikan

Menurut Siswoyo (2017) mengatakan bahwa analisis pengaruh yang ditujukan untuk melihat seberapa kuat pengaruh suatu variabel dengan variabel lainnya baik secara langsung maupun tidak langsung. Interpretasi dari hasil ini akan memiliki arti yang penting untuk menentukan strategi yang jelas dalam meningkatkan pencegahan Fraud dalam pengelolaan keuangan Desa di Kabupaten Tangerang. Hasil perhitungan pengaruh langsung, tidak langsung dan pengaruh total oleh Amos 22 sebagai berikut :

Tabel 5. Pengaruh Langsung (Standardized Direct Effects (Group number I - Default model)

\begin{tabular}{|c|c|c|c|c|}
\hline & $\begin{array}{l}\text { kompete } \\
\text { ni__sdm }\end{array}$ & $\begin{array}{l}\text { sistem_ze-1 } \\
\text { sendalian }\end{array}$ & $\begin{array}{l}\text { imiplemen } \\
\text { bsi } M g\end{array}$ & $\begin{array}{l}\text { percegah } \\
\text { sn_taud }\end{array}$ \\
\hline irplesrenzai gy & 319 &, 510 & .090 & $\mathrm{cos}$ \\
\hline pencegaาar fraud & 285 & 117 &, 482 & $C 00$ \\
\hline
\end{tabular}

Sumber : Analisis hasil penghitungan, 2018

Berdasarkan hasil perhitungan diatas pengaruh langsung kompetensi SDM terhadap implementasi good governance sebesar 0,319. Nilai 0,285 merupakan pengaruh kompetensi SDM terhadap pencegahan Fraud, sedangkan sistem pengendalian Internal terhadap implementasi good governance paling besar sebesar 0,510 dan pengaruh terkecil sebesar 0,117 sistem pengendalian internal terhadap pencegahan Fraud. Begitu juga implementasi good governance terhadap pencegahan Fraud sebesar 0,482 .

Tabel 6. Pengaruh Tidak Langsung (Standardized indirect Effects (Group number I - Default model)

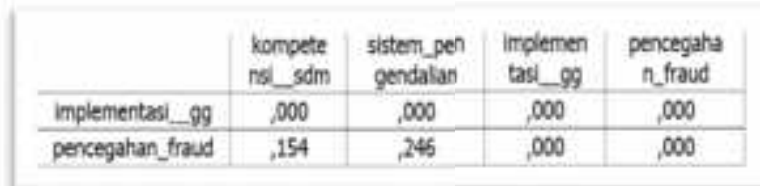

Sumber : Analisis hasil penghitungan, 2018
Berdasarkan hasil perhitungan diatas pengaruh tidak langsung kompetensi SDM terhadap terhadap pencegahan Fraud sebesar 0,154 , sedangkan sistem pengendalian Internal berpengaruh terhadap pencegahan Fraud. Begitu juga implementasi good governance terhadap pencegahan Fraud sebesar 0,246.

Karena pengaruh langsung kompetensi SDM terhadap implementasi good governance sebesar 0,319 lebih besar dari pengaruh tidak langsung kompetensi SDM terhadap terhadap pencegahan Fraud sebesar 0,154. Begitu juga pengendalian Internal terhadap implementasi good governance paling besar sebesar 0,510 lebih besar dari implementasi good governance terhadap pencegahan Fraud sebesar 0,246, maka dapat disimpulkan bahwa variabel implementasi good govenance bukan merupakan variabel intervening.

\section{Tabel7. Pengaruh Total (Standardized Total Effects (Group number I - Default}

\begin{tabular}{|c|c|c|c|c|}
\hline & $\begin{array}{c}\text { kompete } \\
\text { edir }\end{array}$ & $\begin{array}{l}\text { sistor_pon } \\
\text { gonculan }\end{array}$ & $\begin{array}{l}\text { mplomen } \\
\text { taxi_gg }\end{array}$ & $\begin{array}{l}\text { ocncogah } \\
\text { an_fraud }\end{array}$ \\
\hline implementas ig & 319 & .510 & .000 & .003 \\
\hline pencegahar_traud & .138 & .363 & .482 & .000 \\
\hline
\end{tabular}

Sumber : Analisis hasil penghitungan, 2018

Hasil perhitungan diatas pengaruh total dari kompetensi dan sistem pengendalian internal terhadap implementasi good governance menunjukkan bahwa sistem pengendalian internal memiliki pengaruh total yang besar 0,510 daripada kompetensi SDM sebesar 0,319. Kemudian hasil penghitungan pengaruh total kompetensi dan sistem pengendalian internal terhadap pencegahan Fraud, hasilnya menunjukkan pengaruh kompetensi SDM lebih besar 0,438 terhadap pencegahan Fraud dibandingkan dengan sistem pengendalian internal sebesar 0,363, dan implementasi sebesar 0,482. Dengan demikian, variabel Kompetensi sumber daya manusia jauh lebih dominan dibandingkan dengan variabel Implementasi good governance dan Pengendalian Internal dalam mempengaruhi Pencegahan Fraud dalam pengelolaan keuangan desa di Kabupaten Tangerang.

Sependapat dengan hasil penelitian Gede Pose Raharja dkk (2015) Hasil penelitian ini menunjukkan secara parsial akuntabilitas berpengaruh signifikan terhadap pencegahan Fraud organisasi, pengendalian Internal tidak berpengaruh signifikan terhadap pencegahan 
Fraud organisasi dan pengawasan internal berpengaruh signifikan terhadap pencegahan Fraud organisasi.

Secara simultan penelitian ini menunjukkan bahwa akuntabilitas, pengendalian Internal dan pengawasan internal secara bersama-sama berpengaruh signifikan terhadap pencegahan Fraud organisasi. Dengan demikian penelitian diatas sesuai dengan penelitian sebelumnya yang berkaitan dengan analisis pengaruh sistem pengendalian internal, dan kompetensi sumber daya manusia, terhadap implementasi good governance serta impikasinya pada pencegahan Fraud yakni (Agusyani et al., 2016; Herman, 2013; Kadek et al., 2017; Meldawati Girsang, 201 I; Oktariani Wefa, 2017; Ratnayani et al., 2014; Ristanti et al., 2014; Soleman, 2013; Washliati, 20I5).

\section{PENUTUP}

\section{Kesimpulan}

Dari uraian pembahasan di atas dapat ditarik kesimpulan dan saran sebagai berikut :

I. Sistem Pengendalian Internal berpengaruh positif terhadap Implementasi Good Governance. Terdapat pengaruh positif efektivitas Pengendalian internal Terhadap pencegahan Fraud. Terdapat Pengaruh positif Kompetensi Sumber Daya Manusia terhadap Implementasi Good Governance, terdapat Pengaruh secara positif kompetensi sumber daya manusia terhadap Implementasi Good Governance, terdapat pengaruh yang positif implementasi good governance terhadap pencegahan Fraud. Sehingga pengelolaan keuangan dana desa dapat dioptimalkan dengan baik, untuk itu kedepan perlu adanya komitmen yang tinggi bagi aparatur desa untuk terus meningkatkan pelaksanaan Implementasi Good Governance sehingga pencegahan Fraud dalam pengelolaan keuangan desa dapat berjalan lancar

2. Hasil perhitungan diatas pengaruh langsung kompetensi SDM terhadap implementasi good governance sebesar 0,319. Nilai 0,285 merupakan pengaruh kompetensi SDM terhadap pencegahan fraud, sedangkan sistem pengendalian Internal terhadap implementasi good governance paling besar sebesar $0,5 \mathrm{I} 0$ dan pengaruh terkecil sebesar 0, I I 7 sistem pengendalian internal terhadap pencegahan fraud. Begitu juga implementasi good governance terhadap pencegahan fraud sebesar 0,482. Penelitian ini telah menghasilkan gambaran tentang Pengendalian Internal, dimana jika dibandingkan dengan dimensi lainnya maka dimensi jenis Pengendalian Internal dalam bentuk Lingkungan Pengendalian, Penilaian, Risiko dalam kegiatan Pengendalian Internal. Hasil penelitian tentang gambaran Pencegahan Fraud pada dimensi iklim budaya jujur, keterbukaan, dan saling membantu dalam kategori cukup/sedang, peningkatan pengawasan masyarakat sehingga kredibilitas dan integritas lembaga Pengelolaan Keuangan Desa dapat ditingkatkan

\section{Saran}

Adapun saran yang dapat diberikan oleh peneliti sebagai berikut :

I. Perlu adanya memperbaiki penyusunan dan pembuatan program pembinaan perangkat desa dalam rangka pengelolaan keuangan desa yang baik sehingga bisa dicegah kecurangan yang dilakukan oleh perangkat desa.

2. Terus melakukan upaya peningkatan kemaampuan dan kompetendi aparatur desa sehingga dapat melaksanakan tugas dan pekerjaan sesuai dengan yang diharapkan

3. Perlu adanya komitmen yang tinggi bagi aparatur desa untuk terus meningkatkan pelaksanaan Implementasi Good Governance sehingga pencegahan Fraud dalam pengelolaan keuangan desa dapat berjalan lancar, efesiensi anggaran, dan pentingnya keterlibatan masyarakat dalam setiap kegiatan desa demi mendapatkan kemaslahatan baik pada aparatur desa maupun pada masyarakat.

\section{DAFTAR PUSTAKA}

Agusyani, K. S., Sujana, E., \& Wahyuni, M. A. 2016. Pengaruh Whistleblowing System Dan Kompetensi Fraud Pada Pengelolaan Keuangan Penerimaan Pendapatan Asli Daerah ( Studi Pada Dinas Pendapatan Daerah Kabupaten Buleleng ). E-Journal SI Ak Ak, I.

Antonius Galih Prasetyo \& Abdul Muis. 2015.

Pengelolaan Keuangan Desa Pasca 
UU No. 6 Tahun 2014 Tentang Desa: Potensi Permasalahan Dan Solusi, Jurnal Desentralisasi Volume I3, No.I.

BAPPENAS dan BPS, 2016

BPS Provinsi Banten 2018

Bappeda Kab. Tangerang 2017

Badan Pengawasan Keuangan dan Pembangunan RI. 2015

Direktorat Permukiman dan Perumahan. 2009.

Ferdinand, Augusty, 2014, Metode Metode

Penelitian Manajemen, UNDIP Press ISSBN 979-704-254-5. Semarang

Fikri, Ali., Biana Adha Inapty dan Rr. SriPancawati Martiningsih. 20I5.Pengaruh Penerapan

StandarAkuntansi

Pemerintahan,Kompetensi

Aparatur dan PeranAudit Internal terhadap KualitasInformasi Laporan Keuangandengan Sistem Pengendalian Internsebagai Variabel Moderating (StudiEmpiris Pada SKPD-SKPD diPemprov. NTB). SimposiumNasional Akuntansi XVIII, Medan

Halim, Abdul, 20l0. Akuntansi Keuangan Daerah (Akuntansi Sektor Publik), Edisi 3, Salemba Empat, Jakarta

Herman, L. 2013. Pengaruh Keadilan Organisasi dan Sistem Pengendalian Intern terhadap Kecurangan. Pengaruh Keadilan Organisasi Dan Sistem Pengendalian Intern Terhadap Kecurangan, $|-2|$.

https://doi.org//0.1017/CBO978 I 1074 I 5324.004

Ikatan Akuntansi Indonesia (IAI). 200I. Standar Profesional Akuntan Publik. Salemba Empat, Jakarta

Kadek, Wijaya, D. S., Sujana, E., \& Purnamawati, I. G. A. 2017. Pengaruh Efektivitas Pengendalian Internal, Kesesuaian Kompensasi, Moralitas Individu, Dan Whistleblowing Terhadap Kecenderungan Kecurangan Akuntansi Pada Lpd Di Kecamatan Gerokgak. E-Journal SI Ak Universitas Pendidikan Ganesha, 7 No: I Tahun 2017

Komite Nasional Kebijakan Governance (KNKG). 2008. Pedoman Sistem Pelaporan Pelanggaran - SPP (whistleblowing system - WBS). Jakarta: KNKG http://www.bps.go.id

https://bantensatu.com

http://www.wartaekonomi.co.id

Martani, Dwi., \& Fazri Zaelani. 201l. Pengaruh Ukuran, Pertumbuhan, dan Kompleksitas terhadap Pengendalian Intern Pemerintah Daerah (Studi Kasus di Indonesia). Simposium Nasional Akuntansi

Meldawati Girsang. 20II. Pengaruh Sistem Pengendalian Intern Pemerintah, Implementasi Standar Akuntansi Pemerintahan, Penyelesaian Temuan Audit, Kompetensi Sdm Terhadap Kualitas Laporan Keuangan Pemerintah Daerah Dengan Penerapan Good Governance Sebagai Variabel Moderating. Univeritas Sumatera Utara. https://doi.org//0.1007/s/3398$0 \mid 4-0173-7.2$

Mulyadi. 200I. Sistem Akuntansi. Edisi Ketiga. Yogyakarta: YKPN.

Noerma Alifahrani Bahtiar, 2017, Partisipasi Masyarakat Dalam Pengawasan Program Alokasi Dana Desa (Add) Di Desa Panjunan, Kecamatan Sukodono, Kabupaten Sidoarjo. Skripsi Thesis, Universitas Airlangga

Oktariani Wefa. 2017. Pengaruh Implementasi Good Coorporate Governance, Pengendalian Intern Kas, Asitmetri Informasi terhadap Fraud. Jom Fekon, 4 (I). Retrieved from file:///C:/Users/LENOVO G40/Desktop/Pengaruh Implementasi Good Governance, Pengendalian Intern Kas, Asitemri Informasi terhadap Fraud.pdf

Peraturan Pemerintah Nomor 22 Tahun 2015 sebagai perubahan atas Peraturan Pemerintah Nomor 60 Tahun 2014 tentang Dana Desa

Purwitasari, Anggit. 2013. Pengaruh Pengendalian Internal dan Komitmen Orga nisasi dalam Pencegahan Fraud Pengadaan Barang (Survey pada 5 Rumah Sakit di Bandung). Skripsi. Jurusan Akuntansi Universitas Widyatama Bandung.

Puspasari, Novita, \& Eko Suwardi. 2012. Pengaruh Moralitas Individu dan Pengendalian Internal terhadap Kecenderungan Kecurangan 
Akuntansi: Studi Eksperimen pada Konteks Pemerintahan Daerah. Simposium Nasional Akuntansi XV, Banjarmasin

Ratnayani, P. A., Sujana, E., Ari, N., \& Darmawan, S. 20I4. Pengaruh Pengendalian Intern Kas Dan Implementasi Good Governance Terhadap Fraud (Studi Empiris pada SKPD di Kabupaten Buleleng). E-Journal SI Ak Universitas Pendidikan Ganesha, Vol: 2 No:(I).

Ristanti, N. M. A., Sinarwati, N. K., \& Sujana, E. 20I4. Pengaruh Sistem Pengendalian Intern, Pengelolaan Keuangan Daerah Dan Komitmen Organisasi Terhadap Penerapan Good Governance. Jurnal Akuntansi, 2(I), I-II. Retrieved from file:///C:/Users/LENOVOG40/Desktop/P engaruh sistem pengendalian intern, pengelolaan keuangan daerah dan komitmen organisasi terhadap good governance.pdf

Reasoa, Imelda. 20I5. Pengelolaan Keuangan Desa

Salindeho, Mario Mc. A. 2012. Implementasi Etika Pemerintahan dalam Meningkatkan Kinerja Aparatur Pemerintah

Sunyoto, Danang, 2012. Manajemen Sumber Daya Manusia, Cetakan I, CAPS, Yogyakarta

Siswoyo Haryono, 2017Metode SEM untukpenelitian Manajemen AMOS Lisrel PLS, PT. Luxima Metro Media. Jakarta

Soleman, R. 2013. Pengaruh Pengendalian Internal Dan Good Corporate Governance

Taufik, Taufeni. 2008. Pengelolaan Keuangan Desa dalam Sistem Keuangan Negara Republik Indonesia. Jurusan Akuntansi Fakultas Ekonomi Universitas Riau

$F$ adilah, $S$ ri. 20II. Pengar uh Implementasi Pengendalian Intern dan Total Quality Management Terhadap Penerapan Good Governance (Studi pada Lembaga Amil Zakat Seluruh Indonesia). Simposium Nasional Akuntansi XIV. Universitas Syiah Kuala, Banda Aceh

Taufik Kurrohman, 2008, Akuntabilitas Pengelolaan Alokasi Dana Desa Di
Kabupaten Jember. Jurnal Riset Akuntansi Dan Keuangan, 2 (3), 2014, 473-485 Vol.2 | No.3.

Taufik, Mochammad. 2008. Pengaruh pengalaman kerja dan pendidikan profesi auditor internal terhadap kemampuan mendeteksi fraud. Skripsi. Universitas Islam Negeri Syarif Hidayatullah

Undang-Undang Nomor 6 Tahun 2014 tentang Desa

Wardoyo, Hasto. 20I5. Penguatan Pengelolaan Keuangan Desa dan Optimalisasi Peran BUMDesa sebuah upaya menuju Desa Mandiri dan Kredibel di Kabupaten Kulon Progo. Seminar Nasional Temu Forum Dosen Akuntansi Sektor Publik 2015, Universitas Atma Jaya Yogyakarta

Washliati, L. 20I5. Skripsi pengaruh kompetensi sumber daya manusia dan budaya kerja dalam mewujudkan good governance di inspektorat kabupaten labuhanbatu utara. Universitas Sumatera.

Widiyastuti dan Pamudji. 2009. pengaruh kompetensi, independensi, dan profesionalisme terhadap kemampuan auditor dalam mendeteksi kecurangan (fraud). Skripsi Universitas Diponegoro Semarang. 